\title{
KEY ISSUES IN SINO-JAPANESE RELATIONS CONTINUITY AND CHANGE SINCE THE TIANANMEN INCIDENT
}

\section{Nakai Yoshifumi}

This paper focuses on two aspects of Sino- Japanese relations: the structure in which these relations have evolved in the past feelv decades; and the dynamics of the relations after recent historic events. This paper concludes with an assessment of present Sino-Japanese relations in an age of uncertainty.

Despite tremendous changes in the international environment, Sino - Japanese relations in the first few years of the 1990s seem to be showing remarkable strength and cordiality compared to previous decades. The future of these relations is, however, full of uncertainties. Sino-Japanese relations have succeeded in shaking off some of the historical burdens but, at the same time, we are entering into uncharted territory where the old framework is less relevant.

The Tiananmen Square Incident dramatically changed Western perceptions of the PRC government. According to US public opinion surveys of China, the percentage of those who answered favorable to China dropped sharply after the Incident ${ }^{1}$. The same was true in Japan, although the direct impact of the Incident might have been stronger in the United States, where more than one hundred thousand Chinese students and scholars, some of them politically active, had been staying. The Bush administration imposed its first series of sanctions against China immediately after the crackdown in Beijing and took the initiative in formulating a broad coalition of Western nations. The European Community decided to postpone economic aid to China in June. In the subsequent meeting of the Group of Seven in Paris in July, Japan joined the list of nations suspending economic assistance programs to Beijing ${ }^{2}$.

The Bush administration's policy was not so different from Japan's basic attitude, imposing limited sanctions and, at the same time, preserving a viable working relationship with Beijing by maintaining channels of communication with the Cheese government. Perhaps the Japanese government was more earnest in emphasizing continuing communication with the Chinese government. In the July Summit, Japan insisted that a clause, which specifically mentioned the need to avoid isolating China, should be included in the Summit Declaration $^{3}$. 
In 1989 Japan was not in a position to initiate its own policies toward China, which might discourage joint efforts by the United States and other Western countries. Economic friction between Japan and the United States had reached a crisis point in May 1989, when the US government accused Japan of unfair trade conduct and threatened to impose sanctions based on the Super 301 legislation. The Japanese government, therefore, had to synchronize its policies toward China with those of the United States carefully. In July 1989 President Bush secretly sent National Security Adviser Brent Scowcroft and Deputy Secretary of State Lawrence Eagleburger to Beijing to meet with senior Chinese leaders, including Deng Xiaoping ${ }^{4}$. They visited Beijing again in December. At the same time, Japan and China started exchanging several semiofficial visits.

The Japanese Ministry of Foreign Affairs has walked a fine line in continuing communication with the Chinese government and not eliciting antagonistic reactions from the United States. There has been an organizational memory or know-how within the Ministry dealing with this delicate matter. Quite a few top level officials of the Japanese Foreign Ministry had already engaged in negotiations with the PRC on various issues since the normalization of diplomatic relations. These officials have contributed to maintaining the continuity of Japan's basic standpoint toward China throughout the crisis.

China refrained from criticizing Japan. In July 1989, Prime Minister Li Peng expressed his appreciation of Japan's fair attitude toward the recent suppression of the riot in Beijing. In September Li Peng told an LDP delegation that he expected Japan to play a role in breaking strained relations with the Western countries. Li also allowed the forced repatriation of illegal Chinese immigrants in Japan. This decision greatly alleviated Japanese concerns about the increasing wave of illegal Chinese immigrants. On the same occasion, Deng Xiaoping said that he understood Japan's special circumstances and commented favorably about Japan's attitude toward China ${ }^{4}$.

Despite these signals from China, Japan proceeded carefully by synchronizing its actions with those of the United States. A breakthrough in Chinese-US relations came in June 1990 when the Chinese government allowed the departure of Fang Lizhi, a renowned dissident, to the United States and President Bush renewed China's most favored nation trade status for a year. Right after this, in July, Prime Minister Kaifu Toshiki announced to President Bush that Japan would resume the third yen loan to China, which had been frozen since the Tiananmen Incident. By this time, the Japanese side had done enough groundwork to proceed with the resumption. China had already sent a minister-level 
delegation under the Director of the State Planning Commission Zou Jiahua to Japan in January 1990. In early 1991, several incumbent ministers of the Kaifu administration visited China and the Chinese side responded with visits by Minister of Foreign Economic Relations and Trade Li Lanqing and Minister of Foreign Affairs Qian Qichen.

The Chinese government arranged a "special welcome" for Prime Minister Kaifu Toshiki in August 1991, which indicated the full recovery of Sino-Japanese relations. For the PRC government, this visit was an opportunity to show the world that China had become stable again after the Incident in Beijing. The Japanese side, on the other hand, wanted to show its initiative in nuking economic aid to political improvement. Kaifu promised a yen loan for the year of 1991 amounting to 130 billion yen, a clear signal of Japan's continuous support of China's reform and liberalization policy. At the same time, Kaifu told Prime Minister Li Peng that Japan would take into account several conditions for economic assistance. Japan would link, Kaifu announced, its economic assistance to military expenditures and to the degree of democracy in recipient nations. Kaifu also mentioned that Japan would appreciate China's participation in the Nuclear Non-Proliferation Treaty and its positive commitment to the international restriction of arms sales. Finally, Kaifu even touched on a sensitive question of democracy and human rights, expressing the concerns of the international community about democratization and human rights in China ${ }^{5}$.

Kaifu's visit indicated an emerging new trend in Sino-Japanese relations after the 1989 crisis. Japan continued its economic commitment to China and, at the same time, became more outspoken politically, expressing its opinions which were not exclusively Japan's own but were common among the Western nations, to China. China basically accepted this change, differentiating Japan's stance from the United States and emphasizing the common interests of Japan and China in maintaining stability and prosperity in Asia.

This emphasis on Asia and the special relations between Japan and China originated from strategic and economic considerations. Strategically, China felt the need to improve its relations with its Asian neighbors, Vietnam and South Korea in particular. The Gulf War in early 1990 clearly showed the supremacy of the fighting power of the United States and the strength of the joint intervention organized by the United Nations. Economically, China and Japan shared recognition that Asia, as a region, had accumulated formidable economic strength and had tremendous potential to become the driving force of the world economy. This recognition led to a confidence in the economic relations between China 
and Japan. Sino-Japanese trade, which showed downward trends in 1989 and 1990, rose again in 1991.

Right after Kaifu's visit in August 1991, conservative Russian leaders planned a coup, which soon failed and eventually led to the resignation of Gorbachev and the collapse of the Soviet Union and the dissolution of the Soviet Bloc offered proof to liberal thinkers and Tiananmen dissidents who think that the life of the Chinese Communist Party is limited. On the other hand, instability and economic disorder in Eastern Europe make the relative stability and economic prosperity of China stand out. Hi regard to Sino-Japanese relations, this period was marked by progression, not regression, in mutual relations.

Seeing the coup in Moscow unfolding and collapsing, China displayed some nervousness. By the end of 1991, however, the Chinese leaders seemed to have recovered their confidence in their rule 7 . They started expressing the opinion that China's situation was different from that of the former Soviet Union. In the new year of 1992, China's paramount leader, Deng Xiaoping, took a trip to the Special Economic Zones in Guangdong province. His speeches during the trip became Party Central Directive Number Three, which was endorsed by the Party Central Committee and distributed widely in March. Deng ordered the Chinese leaders to take bolder measures in the pursuit of economic reform and liberalization. Economic development was. According to Deng, the 'life or death' questions for the Chinese Communist Party.

The Soviet Union collapsed, Deng continued, because it failed to reform its economy and lost the support of the general populace. This endorsement of the economic reform policy by Deng during his "southern trip" triggered the massive flow of foreign capital into China.

In diplomacy, the collapse of the Soviet Union encouraged the tendency within the Chinese leadership to direct most of China's diplomatic effort and energy towards the only remaining superpower, the United States. The United States not only displayed its superior military force in the Gulf War but also continued pressing China on the issues of trade imbalance and human rights. The PRC government strongly opposed moves within the United States to link most favored nation status to improvement in human rights conditions. On several occasions nice 1991, however, China has engaged in intensive negotiations with US government officials over economic issues, such as intellectual property rights and market access, and conceded to US demands ${ }^{8}$. On the question of most favored nation status, China and the United States have established a scheme to avoid outright confrontation. 
In sum, the general policy directions of the Chinese government since the summer of 1991-the promotion of further economic reform and the avoidance of confrontation with the United States-matched Japan's policy orientation and benefited Sino-Japanese relations. Party General Secretary Jiang Zemin's visit to Tokyo in April 1992 and Emperor Akihito's visit to China in October symbolized the good relationship between Japan and China. Jiang's visit displayed not only Japan's goodwill toward the present Chinese leadership but also Japan's appreciation of the stability in Asia. Japan supported not only China's push toward further economic reform but also China's commitment to a good neighbor policy in Asia ${ }^{9}$. China established diplomatic relations with Israel in January and with South Korea in August, and it was reported that fifteen heads of state visited China in 1992, including Boris Yeltsin of Russia in December.

Despite historical burdens recent changes in the international context, or perhaps because of them, China and Japan have succeeded in establishing a cordial working relationship. The economic relationship which had been the constant theme of Sino- Japanese relations since the early days has proven to be sturdy despite time and political changes. The political relationship seems to be taking a more independent course than before. It had been dependent on China's relationship with the United States and the Soviet Union in the past. Since the end of the US-Soviet Cold War, both China and Japan seem to be searching for a new international framework. During these transitions, China and Japan seem to be relying on the old principle of the "separation of economics from politics."

After Emperor Akihito's visit, no serious issue has appeared in Sino Japanese relations until last June when Taiwan's Lee Denghui visited the United States. This does not necessarily prove the stability of the relationship, however. With their economic accomplishments in mind, both Japan and China seem to have become more assertive in their foreign policies. Japan's initiative in linking economic assistance to democratization coincided with its move toward accepting an increasing role in international peace keeping operations, exemplified by its decision to send Self-Defense Forces to Cambodia in 1992. China must have become uneasy about Japan's growing political influence as China has also showed its political assertiveness on several occasions. China's defense budget has been growing more than ten percent each year since 1989, and recorded twenty percent increase in 1994. China has passed its own Maritime Law which claims China's sovereignty over disputed territories in the East and South China Sea. It has also repeatedly conducted nuclear tests, ignoring international concerns about nuclear proliferation and Japan's requests for restraints. 
Besides political assertiveness, we are facing growing economic competition and inevitable political uncertainty. China, which had turned into the importer of two basic commodities, crude oil and grain, must seek, together with Japan, stable sources for those resources. China and Japan are already the two largest exporters to the United States. As its industrialization goes on, China would concentrate on producing more value-added goods, and that course may lead to a collision with Japan. On the political front, the issue of North Korea's nuclear weapons program proved that when the political grip of the Cold War structure loosened, a new set of problems may arise suddenly". Old problems are not completely dead, either ${ }^{12}$. Moreover, China and Japan are facing uncertainty in their domestic politics. Japan has lost one of its most stable political frameworks of the past recently, i.e., the rule of the LDP. China is also facing an inevitable transition in political leadership, i.e., and the death of the paramount leader. We hope the leadership transitions in both Japan and China go on peacefully and smoothly, but as old Japanese saying states, in politics "it is dark one step ahead."

\section{References}

1. Harry Harding, a Fragile Relationship: The United States and China since 1972, (Washington D. C: Brookings Institution, 1992), Table A-1, 363.

2. Harding, a Fragile Relationship, 224-227.

3. Tanaka Akihito, Nitchu kankei 1945-1990 [Sino-Japanese Relations 19451990], (Tokyo: University of Tokyo Press, 1991), 178.

4. Harding, a Fragile Relationship, 228. 5. Tanaka, Nitchu kankei, 180.

6.Tanaka Akihiko, “Tainichi kinkier [Sino-Japanese Relations]," Chugoku saran, (Tokyo: Kazankai, 1992): 127.

7. A Chinese scholar told the author recently that right after the Soviet coup, Deng sent a directive to the Propaganda department. The directive ordered not to speculate the outcome of the coup. When the coup turned out to be a failure, the Party and the government held a series of information meetings in Beijing to study the situation in the Soviet Union as well as in Europe and Asia, hi those meetings, this scholar mentioned, participants were guaranteed free- 
dom of speech, that was, a guarantee not to be persecuted as a promoter of "peaceful revolution (heaping yanbian)."

8.Nakai Yoshifumi, "Beichu keizai masts no Kosei [The Structure of SinoUS Economic Friction], “Nitchu keikyo journal Tokuyo, (July-August 1993): 19,10-28.

9.Nakai Yoshifumi, "From Confrontation to Cooperation: the Chinese view of the world and Southeast Asia since the June 1989 Tiananmen Incident," a paper presented at the Asian Center, University of Philippines, and February 1993, forthcoming.

10. Lomita Kazuhiko, "Zenhoi gaiko no shintenkai [New Development in All-Dimensional Diplomacy], "Chugoku nankeen, (Tokyo:Chugoku kenkyujo, 1993):80-81.

11. North Korea's nuclear issue triggered a set of political debates in Japan, because the Cold War setting largely remains intact in its relations with North Korea. Japan has no official relation with North Korea, except Japan Socialist Party's informal tie with the Labor Party in North Korea. It is believed that a substantial amount of money is flowing into North Korea via pro-North organizations in Japan. One government source told the author that the Carter mission "created" Murayama cabinet. If the US-North Korea accord did not go through and Japan joined the sanction against North Korea, LDP was unlikely to ally with Murayama, whose Socialist Party has close tie with North Korea.

12. War orphans, comfort women, chemical weapons development program in Liaoning, war widows in Sakhalin, and some LDP politicians keep on upsetting Chinese people by their remarks on the last war. 